Öz

Kentlerin okunabilir ve tanımlanabilir olması, kentlilerin aidiyet, güvenlik, sosyalleșme, yer-yön bulma gibi temel ihtiyaçlarının giderilebilmesi ve insan-çevre ilișkilerinin olumlu yönde geliștirilmesi adına gereklidir. Bir kentin söz konusu özellikleri içeren ve kentlilerin yaşam kalitesini arttıran nitelikli bir kent olup olmadığı, çevresel algı ve kentsel imge çalıșmalarıyla ortaya konarak değerlendirilebilmekte ve gerektiğinde iyileștirmeler yapılabilmektedir. Bu nedenle çevresel algı çalıșmalarının ampirik düzlemde geliștirilmesi ve yeni yaklaşım biçimlerinin uygulanması önemlidir. $\mathrm{Bu}$ araștırmada yöntem olarak durum çalışması (case study) gerçekleştirilmiș, İzmir kent merkezinin önemli yerleșimlerinden biri olan Karșıyaka çalıșma alanı olarak seçilerek çevresel algısı çözümlenmiștir. Çalışmada anı, hafiza, duygu, düsünce ve davranısları olușturan bilișsel (cognitive) ve duygusal (affective) algı süreçleri bütünde ele alınmıștır. Bu kapsamda öncelikle literatür taraması ile araștırmanın kuramsal modeli ortaya konmuș, alan çalıșmasında tesadüfi olarak seçilen katılımcılarla açık uçlu sorulardan olușan yarı-yapılandırılmıș görüșmeler gerçekleștirilmiș ve Lynch'in bilișsel haritalama yöntemi uygulanmıștır. Elde edilen verilerin analiz edilmesiyle, çalıșma alanı olarak seçilen Karșıyaka'nın çevresel algısı ve kentsel imgesi çözümlenmiş, kentsel potansiyelleri ve zayıflıkları ortaya konmuștur. Çalışmanın sonunda Karşıyaka'nın ticari, sosyal, rekreatif ve kültürel açıdan kentliler için nitelikli bir kent deneyimi sunan, çevresel imgelenebilirliği yüksek, kullanıcıları tarafından benimsenmiș, anlamlandırılmıș, olumlu duygusal bağlar kurulan bir yerleșim yeri olduğu sonucuna ulașılmıștır.

\section{Abstract}

Cities' legibility and definability are essential in order to satisfy citizens security, belonging, socializing and navigating needs and to provide a positive human-

environment interaction. Moreover, an urban settlement can be evaluated and ameliorated through environmental perception and city image studies. In this scope, developping empirical environmental perception studies and applying new research approaches are crucial. In this paper, case study has been the method used and the research field has been determined as Karşlyaka, Izmir. Evaluating Karsivaka's environmental perception holistically with cognitive and affective processes of perception which forms memory, emotions and behaviour is the main aim of the study. In this context, firstly the theoretical background has been established through literature research and then field research consisting semistructured interviews including open-ended questions and cognitive mapping has been done with participants chosen by random sampling. Analysing the data derived from this research, Karşlyaka's environmental perception and city image, thus its potentials and weaknesses have been revealed. It is concluded that Karşlyaka is qualified,

\title{
İzmir-Karşıyaka'da Çeuresel Algıyı Çözümlemeye Yönelik Bir Araştırma
}

\author{
(D) Ayşe Imre Özgen \\ Dokuz Eylül Üniversitesi Mimarlık Fakültesi, Mimarlık Bölümü, Bina Bilgisi Anabilim Dalı \\ (iD) Ilknur Türkseven Doğrusoy \\ Dokuz Eylül Üniversitesi Mimarlık Fakültesi, Mimarlık Bölümü, Bina Bilgisi Anabilim Dalı
} Başvuru tarihi/Received: 25.07.2019, Kabul tarihi/Final Acceptance: 11.01 .2020

\section{Giriş}

Kentlilerin tüm bireysel ve sosyo-demografik farklılıklarına rağmen bir araya gelerek sosyalleştikleri ve yaşamlarını sürdürdükleri bir alan olarak tanımlanan kentlerde (Milgram, 1970, 1461), bir arada yașama olgusunun sağlıklı olarak gerçekleștirilebilmesi için nitelikli bir kentsel tasarım son derece önemlidir. Kentsel mekânın algilanabilir ve imgelenebilir olması ve "yerin" olumlu deneyimler sunmas1, insan-çevre iliskileri adına kentsel tasarımın niteliği açısından önemli faktörler olarak öne çıkmaktadır (Lynch, 2018, 3; Yazıcıoğlu Halu, 2010, 56). Nitelikli bir kentsel tasarım, tasarımciyla kullanıcı arasında olumlu ilișkiler kuran, tanıdıklık ve güven hislerini destekleyen, kolayca hareket etmeyi sağlayan okunaklı ve imgelenebilir kentler ve olumlu bir çevresel algı ile mümkün olabilir (Gärling ve Golledge, 1989; Lynch, 2018, 3-5). Çevresel algının, duyular aracılığıyla toplanan bilginin kișisel, psiko-sosyal ve kültürel özellikler ve geçmiş deneyimlerin süzgecinden geçirildiği, bilişsel ve duygusal olarak işlenerek mekânlara anlamlar yüklendiği, çeşitli duygusal ve davranışsal tepkiler oluşturan çok bileşenli karmaşık bir süreç olduğundan bahsedilebilir (Ittelson, 1978; Nasar, 1998, 1). Algılanan mekân ile kişi arasındaki iletişimde ortaya çıkan duygular, davranışlar ve mekana yüklenen anlamlar, görsel ögelerle birlikte kentsel imgeyi oluşturmaktadırlar (Lynch, 2018, 3-7). $\mathrm{Bu}$ anlamda bilişsel ve duygusal süreçleri bir bütün olarak dikkate alan çevresel alg1 ve kentsel imgelemi araștıran ampirik çalıșmalar sayesinde kentli ile bütünleșen ve kentli tarafından anlașılabilen nitelikli kentsel mekânların tasarlanması mümkün olabilmektedir (Gärling ve Golledge, 1989, 203; Ittelson, 1978).

Bu çalışmada amaç, Lynch'in görsel duyuları öne çıkaran İmgelenebilirlik Teorisi'ni çok duyulu kentsel mekan algısına doğru genişletmek ve İzmir kentinin önemli kıyı yerleşimlerinden biri olan Karşıyaka'nın çevresel algısını bilişsel ve duygusal tüm boyutlarıyla birlikte inceleyerek çözümlemektir. Bu kapsamda öncelikle çevresel algı ve kentsel imge olguları açıklanmış, sonrasında, elde edilen bilgilere dayanarak çalışmanın kuramsal alt yapısı oluşturulmuș ve Karşıyaka'da bu kuramsal altlığa gore yapılandırılan bir alan çalışması gerçekleştirilmiş ve Karşıyaka'nın çevresel algısı çözümlenmiştir.

\section{2. Çevresel Algllama ve Kentsel Imgelem}

Fiziksel olarak kent Milgram (1970, s. 1461) tarafindan, çok sayıda insanın heterojen bir șekilde bir arada yaşadı $\breve{g}_{1}$ ve yaşayanlar için çeşitli anlamlara sahip sokak ve yapılar yığını olarak tanımlanırken, sosyal açıdan Schulz'a (1980) göre kent insanların 
bir araya gelmesi için çok çeşitli seçenekler ve dolayısıyla seçme özgürlükleri sunan canlı bir mikrokozmoz" dur. Bunun yanı sira kentler; var olan tarihsel izlere her geçen gün yenilerinin eklendiği, kullanıcıların kendi geçmiş düşünce ve deneyimlerini kamusal mekân kullanımlarına yansıttıkları, kültürel, fiziksel ve sosyal anlamlarda sürekli gelișen dinamik yapılara sahiplerdir (Sağsöz ve Al, 2013, 92; Yazıcıoğlu Halu, 2010, 25; Uz ve Uz, 2017, 723). Kentler, sadece fiziksel çevre ve burada yaşayan insanlardan ibaret değildir. İnsan ve çevresi arasında görülemeyen ancak hissedilen bir ilişki vardır ve bu ilișki aracılığıyla olușan davranışlar kentin şekillenmesinde oldukça etkili olmaktadır (Lewin, 1951). İnsan-çevre ilișkisinin incelendiği çevresel algıya yönelik çalışmaların gerçekleştirilmesiyle kentsel çevrelerin kullanıcıları tarafindan nasıl algılandıkları ve kullanıldıkları olumlu ve olumsuz yönleriyle ortaya çıkarılabilmekte, böylelikle elde edilen veriler doğrultusunda çeşitli düzenlemeler ve planlamalar gerçekleştirilerek daha nitelikli çevrelerin tasarlanması da mümkün olabilmektedir (Gärling ve Golledge, 1989, 203).

Çevresel algı bilișsel boyutlar ve diğer psikolojik süreçlerle beraber işleyen çok boyutlu ve karmaşık bir süreçtir (Ittelson, 1973). İlk aşama çevreden duyu organları yoluyla bilgi edinmektir. Ayna ve Domaniçli duyuyu, insanların gerçekliğe bağlanmasını sağlayan, duyusal reseptörler olarak ișleyen, duyu organları vasıtasıyla çevreden elde edinilen ancak henüz herhangi bir ișlemden geçmemiș ham bilgi olarak tanımlamaktadır $(2011,2)$. Mekân algısı söz konusu olduğunda, görme, ișitme, dokunma, tatma ve koklama olarak beș duyunun devreye girdiği ancak tüm bu duyular içerisinde en baskın olarak görme duyusunun öne çıktığ bilinmektedir (Lefebvre, 2002, Pallasmaa, 2018, 19). Çevreden duyusal olarak edinilen bilginin yaklașı $\% 80$ 'i görseldir ve beyin aktivitelerinin üçte biri görme ile alakalıdır; bu bakımdan görme duyusunun baskınlığı pek de șaşırtıcı değildir (Arnheim, 2018; Eagleman, 2013). Ancak görme duyusunun öne çıkması, diğer duyuların yok sayılması anlamına gelmemelidir zira mekansal deneyim tüm duyulara hitap eder ve çoklu duyusal deneyim gözardı edildiğinde monotonlaşan, derinliğini kaybeden bir mekânsallaşmayla karşı karșıya kalınmaktadır (Lefebvre, 2002; Pallasmaa, 2018, 12; Türkseven Doğrusoy, 2017, 137). Ayrıca, mekan algısının beș duyuyla sınırlı olmadı ̆̆ına dair birçok çalışma bulunmaktadır. Gibson (1966), duyuların sadece bilgi çeken basit mekânizmalar olduğunu reddederek aslında bir arada var olan ve çalışan görsel, ișitsel, tat-koku sistemi, temel yön bulma sistemi ve dokunsal (haptic) sistem olmak üzere beș duyusal sistem olduklarından bahseder (1966). Lange, temel beș duyuya kinestetik ve denge sistemini ekleyerek aslında çevrenin yedi duyu aracılığıyla duyumsandığını ileri sürmektedir $(2005,4)$. Steiner ise dokunma, tatma, görme, koklama, işitme, yaşam, hareket, denge, 1s1, konuşma, düşünme ve benlik olarak toplamda en az on iki adet duyunun varlığından söz eder $(1981,12)$.

Çevresel algının ikinci aşamasında iç içe geçmiş olarak bilişsel (cognitive) ve duygusal (affective) süreçler devreye girer. Bilișsel süreç, duyularla elde edilen ham bilginin Rapoport'un "adlandırma, sinıflandırma ve düzenleme mekanizması" olarak tarif ettiği sistemden geçerek çevreye dair anlamların olușturulma sürecidir (Lynch, 2018; Rapoport, 1977). Bilişsel süreçte kişilerin kișisel özellikleri, değerleri, beklentileri, deneyimleri, kültürel geçmişi ve psiko-sosyal durumu gibi faktörler oldukça etkili ve önemlidir (Ittelson, 1978; Lang, 1994, 26; Lynch, 2018, 1; Nasar, 1998, 1; Rapoport, 1977). $\mathrm{Bu}$ faktörlerin varlığı her kișinin kendi alg1 çerçevesini öznel kılmaktadır (Ittelson, 1978). Algıyı etkileyen önemli faktörlerden biri psiko-sosyal ögeler olarak düşünülebilir; bu ögeler Maslow'un (1954) ortaya koyduğu üzere fizyolojik, güvenlik, aidiyet, statü, sosyalleşme, kendini gerçekleştirme gibi gereksinimlerin sonucunda ortaya çıkmaktadır. Bir diğer önemli faktör ise geçmiș deneyimlerdir. Alg1, bir yerin görülmesi veya tanımlanmasından farklı olarak, duyumsanan uyaranla daha önceki karşılaşmaların varlığı veya yokluğuyla alakalı olarak basit bir gözlem yerine yeni imageable, embraced, sensed, positively percepted and used urban space which provides a fulfilling urban experience in commercial, social, recreative and cultural terms for its users.

Anahtar Kelimeler: İzmir, Karșıyaka, Kamusal Alan, Çevresel Algı, Kentsel İmge, Bilișsel Haritalama

Keywords: İzmir, Karşlyaka, Environmental Perception, Environmental Image, Cognitive Mapping

154 Sayı 29, Mart 2020 
bir keșif olarak tanımlanabilmektedir (İnceoğlu, 2010, 83; Selçuk ve Türkseven Doğrusoy, 2016, 327). Sonuçta bilișsel aşamalardan geçen çevresel bilgi, kişinin çevresine kendine göre bir anlam yüklemesini ve bu sayede çevrenin tanıdıklaşmasını, benimsenmesini ve dolayısıyla kimliğinin oluşmasını sağlar (Karakuş, 2007).

Bilişsel (cognitive) süreçle iç içe olarak alg1lama sürecinin bir diğer boyutu olarak duygusal (affective) süreç ortaya çıkmaktadır.

Bir mekânın benimsenmesi ve kullanılmasinın önemli sebeplerinden biri Mehrabian ve Russell (1974) tarafından Uzaklaşma-Yakınlaşma Teorisi'nde (Avoidence-Approach Theory), kișilerde o mekâna karşı oluşan duygusal bağlar (affective behaviour) olarak tanımlanmıştır. Teoriye göre, mekânla kullanıcısı arasındaki ilișki memnuniyet (pleasure), coşku (arousal) ve baskınlık (dominance) olmak üzere üç temel boyutta açıklanmaktadır. Memnuniyet; kișinin mekândaki mutluluk-mutsuzluk aralığını, coșku; heyecan duyma-sıkılma aralığını, baskınlık ise mekânın baskıcı-özgürlük aralığını belirten boyutlar olarak belirtilir (Bakker, Van der Voordt, Vink ve De Boon, 2014, 407-408). Mekânla kurulan ilișkide duygusal süreç önemli olmakta, olumlu duygular ortaya çıktığında mekana yaklaşma (approach), olumsuz duygular oluștuğunda ise mekandan kaçınma (avoidence) davranıșı gelișmektedir (Mehrabian ve Russell, 1974). Dolay1s1yla kișilerin bir mekânla ilișkili olumlu ya da olumsuz duyguları mekânla kurdukları ilișkinin niteliği hakkında önemli bir gösterge olmaktadır.

Çevresel algıya bağlı olarak gelișen kentsel imgelem süreci Kevin Lynch Kent İmgesi (2018) adlı çalışmasında görsel duyunun belirleyici olduğu İmgelenebilirlik Teorisi (Imageability Theory) ile açıklamaktadır. Lynch, kentsel imgelem sürecini, yaşanan çevrede fiziksel olarak görülen görüntülerin zihinsel süreçlerle anlamlandırılarak ayırt edilen ve odaklanılan imgeler haline gelmesi ve bu imgelerle çevreye ilișkin görsel ipuçlarının oluşturulması ile açıklamaktadir $(2018,9,147)$. Lynch, kentsel imgelerin ayırt edici fiziksel özelliklerin dışavurumu olmasının yanı sıra; kișilerin yer-yön bul- masında, çevreyi çabuk öğrenmesi ve hatırlamasında, daha hızlı ve kolayca hareket etmesinde ve kentin kullanıcıları tarafindan benimsenmesinde çokça etkili olduğunu, bu sebeple kentsel tasarımda kentsel imge olgusunun ciddiyetle dikkate alınması gerektiğini belirtmektedir (2018, 3-5).

Nitelikli bir kentsel imge; kimlik, strüktür ve anlam olmak üzere üç bileșenden oluşmaktadır (Lynch, 2018, 8). Bu üç bileşene sahip olan imgeler; kentin okunabilirliği, tanımlanabilirliği ve kișilerin o mekânda aidiyet, güvenlik, sosyalleșme gibi temel ihtiyaçlarını giderebilmesini sağlayan, sahiplenilen ve kullanılan, nitelikli kentsel mekânların olușmasını sağlamaktadır (Lynch, 2018, 4-5). İlk bileșen olarak kimlik, Lynch tarafından bir varlı̆ğ diğer varlıklardan ayıran ve onun özgünlügünü, biricikliğini simgeleyen olgu olarak tanımlanmıştır. İkinci bileșen olan strüktür; kentin insan eliyle yapılmış-yapılaşmış çevresinde görülen yollar, sinırlar/kenarlar, bölgeler, düğüm/odak noktaları ve işaret ögelerinden oluşmaktadır $(2018,8)$. Yollar; sokak ve cadde gibi hareket alanlarıdır, çevresel imgelerde en belirgin olanlarıdır, sınırlar/ kenarlar; farklı özellikteki bölgeleri ayıran çizgisel elemanlardır; bölgeler; benzer karakterdeki alanların bir araya gelmiș halleridir, düğüm/odak noktaları; kentlerdeki toplanma alanlarıdır ve son olarak işaret ögeleri; kentteki referans noktaları olarak tanımlanabilir (Lynch, 2018, 52-53). Benzer biçimde Appleyard da kentsel imgelerin oluşturulması için en verimli bilgi toplama yönteminin sıklıkla kullanılan akslar ve çevreler olduğunu belirtmiştir (1976). Son bileșen olan anlam, kişilerin çevresel algıları sonucunda mekânlara fiziksel ve duygusal olarak yükledikleri simgesel değerlerdir (Lynch, 2018, 9). Rapoport'un da belirttiği gibi anlamla ilișkili olan kimlik, kişilerin o çevredeki tanıdıklık hissini sağlamasıyla aidiyet ve güven ihtiyacını karşılayan en önemli etmendir (1977). Dolayısıyla bir kentsel alanın kullanıcıları için hangi açıdan önemli olduğu, hangi bileşenlerinin öne çıktığı, günlük hayatlarında hangi kentsel ögeleri kullanıp o yerle ilgili ne gibi hisler beslediğine dair verilerin elde 
edilmesi çok duyulu kentsel deneyime ve kentsel imgeleme dair çıkarımların yapılmasını mümkün kılabilir.

Sonuç olarak, çevresel algıyı çok duyulu biçimde çözümlerken, Lynch'in görsel duyuyu ve bilișsel boyutu (cognitive) öne çıkaran İmgelenebilirlik Teorisi'nin yanı sıra, çevresel algıdaki duygusal (affective) boyutları vurgulayan Mehrabian ve Russell'ın Duygulanım Teorisi'nden de yararlanılarak, çalışmanın çok duyulu kentsel deneyimle çevresel algısına ilişkin kuramsal modeli oluşturulmuștur. Bu modele göre yapılandırılan alan çalışmasında duyguları ve mekana ilișkin yakınlaşma ve uzaklaşma davranışııı ölçmek üzere açık uçlu sorulardan kurulu bir görüşme gerçekleștirilmiș, bu görüşmede aynı zamanda Lynch'in İmgelenebilirlik teorisi kapsamında "Bilișsel Haritalama" yöntemi kullanılmıștır (Şekil 1).

\section{Karşıyaka'nın Çevresel Algısı}

\section{1 Çalış̧ma Alanı}

\subsubsection{Karşıyaka'nın Konumu}

Alan araştırmasının gerçekleștirildiği Karşıyaka ilçesi, Türkiye'nin batısında yer alan İzmir Körfezinin kuzey kıyısında konumlanan bir yerleșim alanıdır (Şekil 2). Komşu ilçeleri; Menemen, Çiğli, Bornova ve Bayraklı ilçeleridir. Kuzeyinde Yamanlar Dağ1 ve güneyinde deniz ile sinırlanan Karşıyaka'da sahil yolu, banliyo tren hattı (İzban), Anadolu Caddesi ve İzmir Çevre-

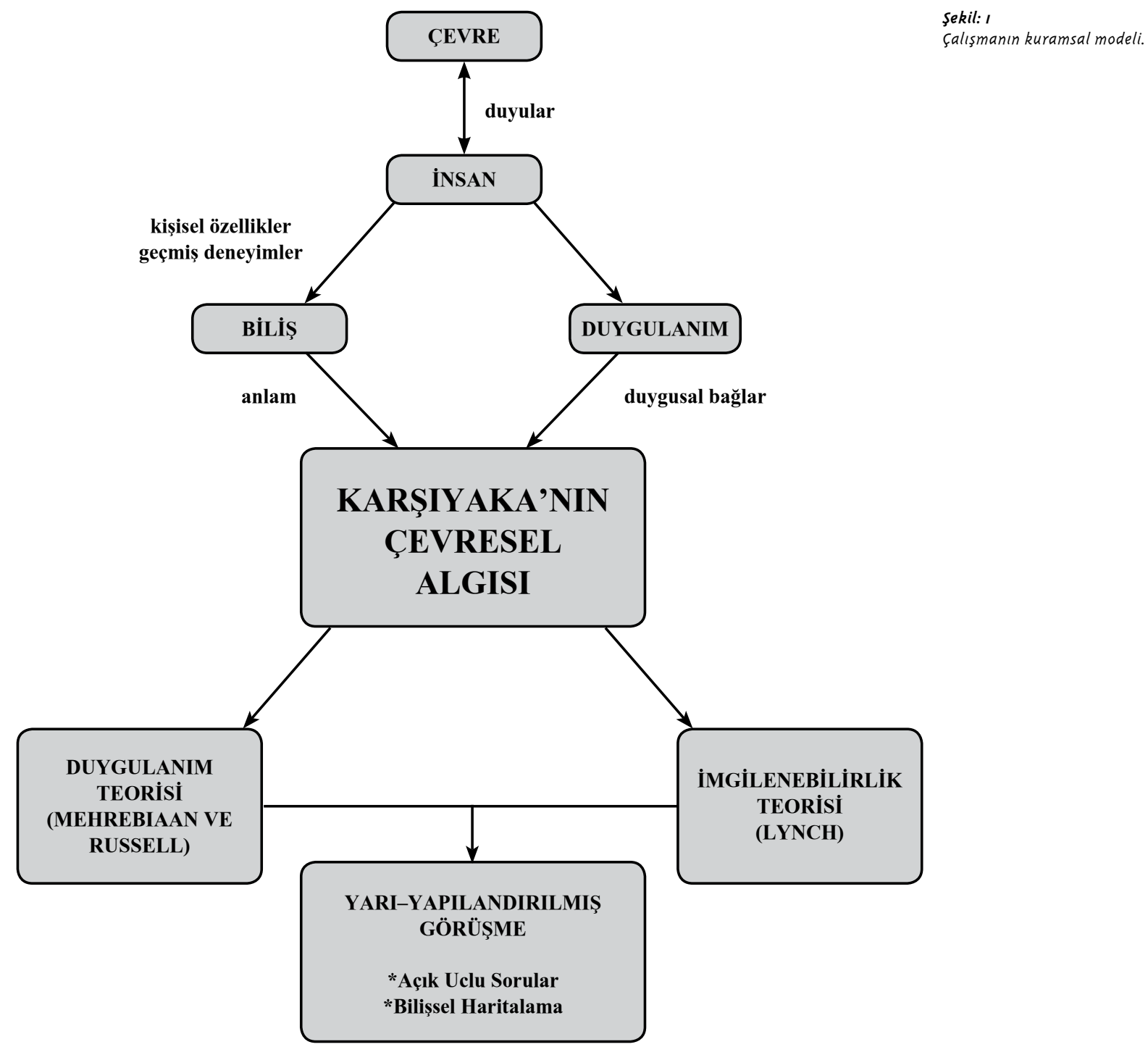


Şekil: 2

Çalışma alanının konumu. sekil: 3

Karşıyaka deniz banyoları, Bahtiyar Karatosun ve Olğun, 2017.

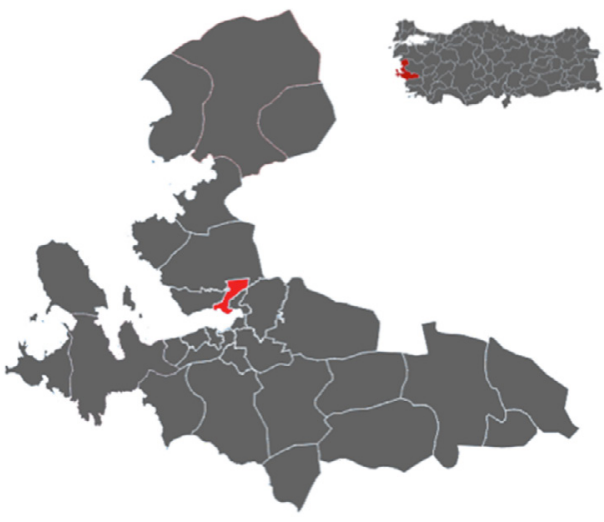

yolu ana ulaşım akslarını oluşturmaktadır. $\mathrm{Bu}$ aksların arasında gelişen kentsel yapıda çoğunlukla konut alanlarının bulunduğu görülmektedir.

\subsubsection{Karşıyaka'nın Tarihçesi}

Karşıyaka eski adıyla Kordelya 19. yüzyıla tarihlenen bir yerleşim olup (Erdoğmuş, 2012, 39; Tanaç Kiray, 2006, 40), ilk yerleşim yerleri kıyı şeridi ve iç kısımda olmak üzere iki farklı bölgede görülmüştür. İç kısımdaki ilk yerleşim Türkler'in yerleştiği bölge olan Soğukkuyu'dur (Sormaykan, 2008, 15). Kıyı şeridi yerleşimi ise; bir ticaret kenti olan İzmir'de ticaretle zenginleşen ve çoğunluğu yabancı kökenli Levantenlerin yazlık köşklerinin bulunduğu, bir sayfiye yeri olarak gelișmiștir (Bahtiyar Karatosun ve Olgun, 2017, 55-56; Erdoğmuş, 2012, 39). Bu köşklerin ön tarafinda denize kadar uzanan bir kamusal alan bulunmakta, bu alan bazı bölgelerde köșk sakinlerinin denize

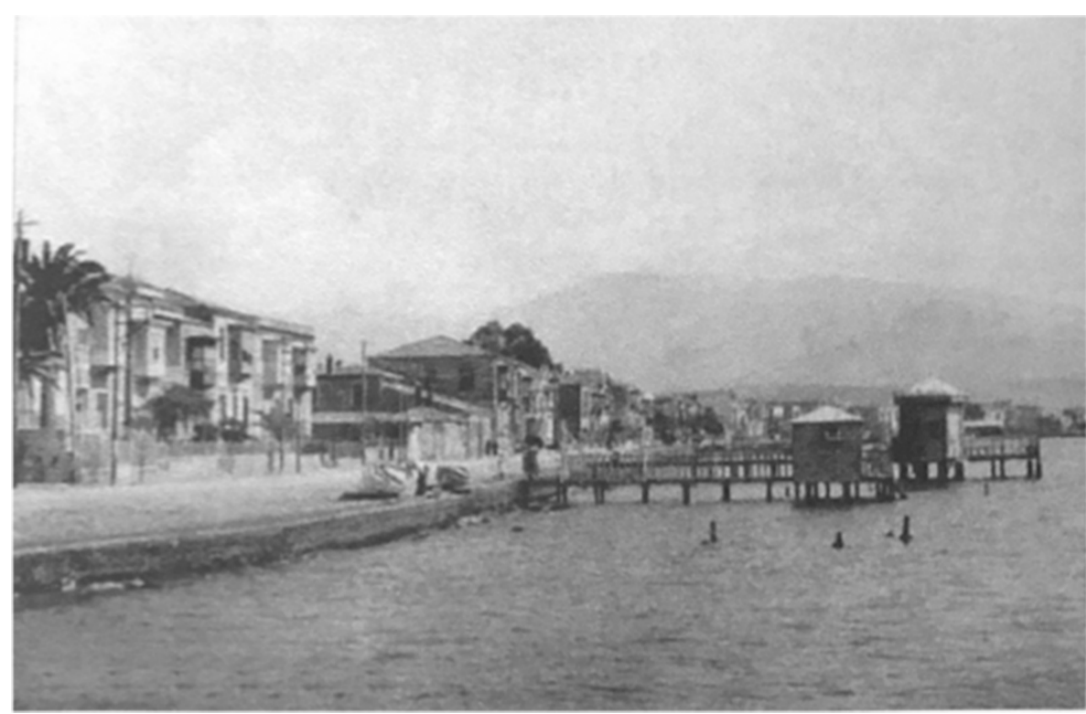

girmesi ve komşularıyla sosyalleşmesi için oluşturulan, dönemin önemli sembollerinden ve yarı özel alan olarak kullanılmasına rağmen Karșıyaka kıyı kamusallığının ilk örneğini oluşturan deniz banyolarıyla bölünmektedir (Bahtiyar Karatosun ve Olğun, 2017, 57; Erdoğmuş, 2012, 39) (Şekil 3).

20. Yüzyılın başlarına gelindiğinde, Yunan işgali ve Kurtuluş Savaşı'nın sonucunda İzmir çok büyük bir yangın geçirerek büyük ölçüde harap olmuştur. Her ne kadar Karşıyaka bu yangından pek etkilenmemiş olsa da, hem İzmir' in genel durumu, hem de sonrasındaki mübadele sebebiyle yaşayan nüfusun azalması Karşıyaka'daki kentsel ve sosyal hayatı oldukça kötü etkilemiştir (Sormaykan, 2008, 19). Bunun sonucunda; kentin yapısına, gelișimine ve değișimine öncülük eden savaş ve mübadele gibi siyasi ve idari etmenler, Karşıyaka'yı çok kültürlü ve hareketli sosyal hayata sahip bir sayfiye bölgesi olmaktan çıkarmış (Karadağ ve Turut, 2013, 35), çok kültürlülüğün ve sosyal hayatın azalarak devam ettiği, konut ve iș yerlerinin çoğaldığı bir 'sürekli yaşam alanı' haline getirmiștir (Tanaç Kiray, 2006, 40). Geç Osmanlı döneminde özel alan olarak kullanılan ancak önemli bir sosyal mekân olan deniz banyolarının tam olarak Erken Cumhuriyet döneminde kamusal kullanıma açıldığı görülmektedir (Erdoğmuş, 2012, 41). Bunlara ek olarak, sosyal odakları olușturan gazino, çay bahçesi, açık hava sinemaları gibi kamusal alanlar kıyı şeridinde ortaya çıkmıștır (Bahtiyar Karatosun ve Olğun, 2017, 59). 1950'ler ve sonrasına gelindiğinde ise sanayileșmenin de etkisiyle büyük göç alan Karșıyaka'da kentsel doku da değișime uğramıș, yazlık köșkler yerine yüksek hacimde konutlar ve ticari yapılar inșa edilmiș, kıyı șeridi doldurularak genișletilmiș, deniz kirliliği sebebiyle deniz kullanımı sınırlanmıș, dolayısıyla gündelik yaşam değișikliğe uğrayarak sosyal hayat kıyı kesimden iç kesimlere doğru yayılmiștır (Bahtiyar Karatosun ve Olğun, 2017, 61; Erdoğmuş, 2012, 41; Sormaykan, 2008, 21).

Günümüzde Karşıyaka, sanayileşmenin çevre ilçelere yayılmasının da etkisiyle, İzmir'in konut alanları yoğun olan en büyük ilçelerinden biridir (İzmir Ticaret Odası [İZTO], 
bt). Ulaşıma bakıldığında Karşıyaka'da çevreyolu, Altınyol ve İzmir Çevreyolu gibi karayolu olanaklarının yanısıra; İzban, tramvay ve deniz yoluyla ulașımın oldukça yoğun ve kolay olduğu görülmektedir. Ulaşımın kolay ve çok seçenekli olması, insan sirkülasyonunu arttırarak ilçenin günlük yaşamda hareketli ve yoğun bir kentsel deneyim yaratmasının en önemli sebeplerinden biri olarak görülebilir. Ayrıca açıkhava tiyatroları, parklar, sosyal tesisler, sahil dolgusunun yenileme çalışmalarıyla rekreatif alana dönüştürülmesi gibi uygulamalar, Karşıyaka'nın geçmişindeki hareketli sosyal hayatın ve kıyı kullanımının kent belleğindeki yerinin korunmasını ve günümüze kadar uzanmasını sağlamaktadır (Sormaykan, 2008, 22).

\subsection{Calıșmanın Yöntemi}

Çevresel algıyı çok boyutlu çözümlemeye dönük kurgulanan bu araștırmada nitel bir araştırma yöntemi olarak durum çalıșması (case study) kullanılmıștır. Çalıșma alanı ise tarihsel arka planı, ulașım bağlantıları ve kıyı kullanımı ile zengin bir altlık oluşturması sebebiyle İzmir-Karșıyaka olarak seçilmiştir. Farklı kullanıcı profilleri içermesi nedeniyle alan çalıșması Karșıyaka'nın farklı coğrafi bölgelerinden Bostanlı Çarșı tramvay durağı, Mavișehir Balıkçı Barınağı ve Alaybey İzban durağı çevresinde gerçekleștirilmiștir. Araștırma, 2018 yılının Kasım ayında iki gün hafta sonu iki gün haftaiçi olmak üzere toplam dört gün içinde tamamlanmıştır. 22 kişiden oluşan örneklem grubu belirtilen çalıșma alanlarında raslantısal olarak seçilen ve çalıșmaya katılmayı kabul eden katılımcılardan olușmaktadır. Araștırmada, veri toplama yöntemi olarak açık uçlu sorular ve bilișsel haritalama bölümlerinden oluşan oluşan yarı yapılandırılmış görüșmeler gerçekleștirilmiștir. Görüșme ve bilișsel haritalama yöntemleri çevresel algı çalıșmalarında sıklıkla kullanılan veri toplama yöntemleridir (Lynch, 2018; Yldirum ve Simșek, 2013, 147). Görüșme, kișilerin hisleri, kișisel özellikleri, deneyimleri, görüşlerine dair detaylı bilgi edinmek için etkili bir yöntem olmakla beraber, yanlıllı̆g ve yönlendiriciliği engellemek adına belirli bir form doğrultusunda yarı yapılandırıl- mıs olarak uygulanabilmektedir (Yldirlm ve Şimşek, 2013, 150-151). Bilişsel haritalama terimi ise ilk kez Tolman (1948) tarafindan mekânlara ilişkin bilgilerin zihinlerde haritaya benzer bir yöntemle depolandığını bulmasıyla kullanılmıștır (aktaran Golledge, 1999, 15). Ancak bilișsel haritalar kapsamlı olarak Downs ve Stea (1973) tarafindan bir kişinin günlük yaşantısındaki çevresine dair bilgi edinmesi, kodlaması, depolaması, anımsaması ve çözümlemesini sağlayan bir dizi psikolojik dönüșümden oluşan bir süreç olarak tanımlanmıștır.

Alan araştırmasında yapılan görüş̧melerde ilk olarak katılımcılara açık uçlu sorular sorularak öncelikle yaşları, öğrenim durumları, ikamet yerleri gibi demografik bilgiler elde edilmiştir. Daha sonra, Karşıyaka'yı ziyaret etme sıklığı, ziyaret sebebi, ulaşım yöntemleri gibi sorular yöneltilerek Karşıyaka'ya karşı hangi davranış biçimi geliștirdikleri Mehrabian ve Russell'ın Uzaklaşma-Yakınlaşma Teorisi bağlamında incelenmiștir. Alınan bu bilgilerden sonra, kullanıcılardan Karşıyaka dendiğinde akıllarına gelen ögeleri, Karșıyaka hakkındaki olumlu ve olumsuz düşünceleri ve duyguları, ve Karşıyaka'daki referans noktaları olarak gördükleri yerleri sıralamaları istenerek sahip oldukları Karşıyaka algısının bilişsel ve duygusal boyutu araştırılmıștır. Açık uçlu soruların ardından, katılımcılardan Karșıyaka'ya dair bir harita çizmeleri istenerek çevresel algının bilișsel boyutu Lynch'in ortaya koyduğu kentsel strüktürdeki görsel bileșenler (yol, sinır, bölge, dïğüm noktası ve işaret ögeleri) bağlamında çözümlenmeye çalıșılmıștır. Veriler içerik analizi yöntemi ile analiz edilerek frekans dökümleri elde edilmiș ve bulgular tartıș1larak yorumlanmıștır.

\subsection{Alan Araştırmastyla Elde Edilen Bulgular}

\subsubsection{Demografik Bilgiler}

Elde edilen veriler analiz edildiğinde örneklem grubunun çoğunluğunun üniversite mezunu, genç ve orta yaş aralığında yer alan, çoğunlukla özel sektör ve kamu çalışanlarından oluş̧uğu görülmektedir. Grupta Karşıyaka'da ikamet edenler çoğunlukta (\%59.1) olmasına karșın farklı yerleșimlerde 
Tablo: I

örneklem grubunun özellikleri.
Tablo: 2

Karşıyaka'nın ziyaret edilme sıklığı frekans dağılımı (\%).

\begin{tabular}{|c|c|c|c|}
\hline & & Frekans (N) & Yüzde (\%) \\
\hline \multirow[t]{5}{*}{ Yaş } & $0-20$ & 1 & 4.5 \\
\hline & $20-40$ & 6 & 27.3 \\
\hline & $40-60$ & 9 & 40.9 \\
\hline & $60+$ & 6 & 27.3 \\
\hline & Toplam & 22 & 100 \\
\hline \multirow[t]{3}{*}{ Cinsiyet } & Kadın & 16 & 72.7 \\
\hline & Erkek & 6 & 27.3 \\
\hline & Toplam & 22 & 100 \\
\hline \multirow[t]{6}{*}{ Öğrenim } & İlkokul & 3 & 13.7 \\
\hline & Ortaokul & 1 & 4.5 \\
\hline & Lise & 5 & 22.7 \\
\hline & Üniversite & 12 & 54.6 \\
\hline & YL/DR & 1 & 4.5 \\
\hline & Toplam & 22 & 100 \\
\hline \multirow[t]{6}{*}{ Meslek } & Özel Sektör & 7 & 31.9 \\
\hline & Yeme-İçme Sektörü & 5 & 22.7 \\
\hline & Eğitim Sektörü & 5 & 22.7 \\
\hline & Ev Hanımı & 3 & 13.7 \\
\hline & Sağlık Sektörü & 2 & 9 \\
\hline & Toplam & 22 & 100 \\
\hline
\end{tabular}

ikamet edenlerin oranı da azımsanmayacak miktardadır. Ancak Karşıyaka dışında ikamet edenlerin çoğu ya Karşıyaka'da çalışmakta ya da geçmişinde Karşıyaka'da yaşamış olduğu için bölgeyi günlük hayatlarında hala aktif olarak kullanmaktadırlar.

\subsubsection{Karşıyaka'daki Ziyaret Davranışına İlişkin Sonuçlar}

Karşıyaka'yı ziyaret etme durumuna bakıldığında, katılımcıların \%59.1'inin Karșıyaka'yı sıklıkla (haftada 3-7 kere) ziyaret ettiği görülmektedir (Tablo 2). Bu gruptaki katılımcıların çoğu Karşıyaka'da ikamet edenlerden, geri kalanı ise Karşıyaka'da çalışanlardan oluşmaktadır. Haftada bir iki kez ziyaret eden katılımcılar, çoğunlukla çalışan ve haftasonları sosyalleşmek veya alışveriş yapmak için Karşıyaka'yı ziyaret edenlerdir. Ayda bir ve nadiren ziyaret eden katılımcıların ise Karşıyaka'dan oldukça uzakta ikamet eden ve çalışan kișilerden oluştuğu görülmektedir. Özetle, çalıșmadaki katılımcı grubunun Karşıyaka’yı günlük yaşantısına çokça dahil etmiş, dolayısıyla çalışmada çevresel algı çözümlemesi açısından çevresel deneyimi fazla olan kișilerden oluștuğu söylenebilir.

Katılımcıların Karşıyaka'da ziyaret ettikleri yerlere bakıldığında \%25 oranla en sık ziyaret edilen yerin Karșıyaka Çarşı, ardından da \%16.6 oranla Mavibahçe AVM ve $\% 14.5$ oranla sahil olduğu görülmüștür

\begin{tabular}{|l|c|c|}
\hline Ziyaret Sıklı̆̆ & Frekans (N) & Yüzde (\%) \\
\hline Sıklıkla / Haftada 3-7 kere & 13 & 59.1 \\
\hline Haftada 1-2 kere & 5 & 22.7 \\
\hline Ayda Bir & 1 & 4.5 \\
\hline Nadiren / Birkaç Ayda Bir & 3 & 13.7 \\
\hline Toplam & 22 & 100 \\
\hline
\end{tabular}




\begin{tabular}{|l|c|c|}
\hline Ziyaret Edilen Yerler & Frekans (N) & Yüzde (\%) \\
\hline Karşıyaka Çarşı & 12 & 25 \\
\hline Mavibahçe & 8 & 16.6 \\
\hline Sahil & 7 & 14.5 \\
\hline Bostanlı Çarşı & 5 & 10.4 \\
\hline Ege Park Mavişehir & 4 & 8.3 \\
\hline Bostanlı İskele & 2 & 4.2 \\
\hline Balıķ̧ı Barınağı & 2 & 4.2 \\
\hline Bostanlı Kafeler & 2 & 4.2 \\
\hline Bostanlı Barlar Sokă̆ı & 1 & 2.1 \\
\hline Karşıyaka İskele & 1 & 2.1 \\
\hline Öğretmenevi & 1 & 2.1 \\
\hline Yamanlar Dağı & 1 & 2.1 \\
\hline Örnekköy Seyir Tepesi & 1 & 2.1 \\
\hline Bostanlı Pazaryeri & 1 & 2.1 \\
\hline Toplam & 48 & 100 \\
\hline
\end{tabular}

Tablo: 3

Örneklemin Karşıyaka'da ziyaret ettiği yerlerin frekans dağılımı (\%).

(Tablo 3). Birkaç katılımcı soruların sadece Karşıyaka Çarşı ile ilgili olduğunu düşünmüş, görüşmenin tüm Karşıyaka ilçesini kapsadığı belirtildiğinde ise bir katılımcı "Benim için Karşıyaka demek Çarşı demek." şeklinde bir açıklama yapmıștır.

Ziyaret edilen yerlere verilen cevaplarla ziyaret nedeni sorulduğunda verilen cevaplara bakıldığında aralarında önemli bir ilişki olduğu görülmektedir (Tablo 4). En çok ziyaret edilen yerlerin çarşılar ve AVM'ler olmasıyla doğru orantılı olarak en önemli ziyaret nedeninin de $\% 21.9$ oranla alışveriş olduğu görülmekte, bunu \%17.2 ve \%15.6 oranlarla sosyalleşme ve yeme-içme aktiviteleri takip etmektedir.

\begin{tabular}{|l|c|c|}
\hline Ziyaret Nedeni & Frekans (N) & Yüzde (\%) \\
\hline Alıșveriş & 14 & 21.9 \\
\hline Sosyalleşmek & 11 & 17.2 \\
\hline Yeme-İ̧̧me & 10 & 15.6 \\
\hline Gezmek & 8 & 12.5 \\
\hline Yürüyüş & 7 & 10.9 \\
\hline İș & 7 & 10.9 \\
\hline Rahatlama & 2 & 3.1 \\
\hline Resmi kurumlar & 3 & 4.8 \\
\hline Kültür-Sanat Aktiviteleri & 2 & 3.1 \\
\hline Toplam & 64 & 100 \\
\hline
\end{tabular}

\subsubsection{Karşıyaka'nın Çevresel Algısına İlişkin Sonuçlar}

Örneklem grubu ile yapılan görüşmelerde, kişisel özelliklere ve Karşıyaka kullanımina dair sorulardan sonra, katılımciların Karşıyaka dendiğinde akıllarına gelenleri ifade etmeleri istenmiștir. Böylece Lynch'in İmgelenebilirlik Teorisi'nde (Imageability Theory) bahsettiği kimlik ve anlam olgularının Karşıyaka özellinde incelenmesi ve Karșıyaka'nın kullanıcıları tarafından hangi yönleriyle öznelleștirildiği, belleklerinde yer ettiği ve imgeleșerek anlamlandırıldığı ortaya konmak istenmiştir. Alınan cevaplar fiziksel ve sosyal olmak üzere iki boyuttan oluşan çevresel bileșenler ile

Tablo: 4

Karşıyaka'yı ziyaret etme nedenlerinin frekans dağılımı (\%). 
Tablo: 5

Karşıyaka ile ilişkilendirilen ögelerin dağılım oranları (\%). psiko-sosyal bileșenler olmak üzere toplam üç kategori altında kodlanmıştır (Tablo 5).

Karşıyaka denince akla gelenlerin gruplandırıldığı üç kategorinin dağılım oranlarına

\begin{tabular}{|c|c|c|c|c|c|}
\hline & & & Akla Gelenler & Frekans (N) & Yüzde (\%) \\
\hline \multirow{18}{*}{ 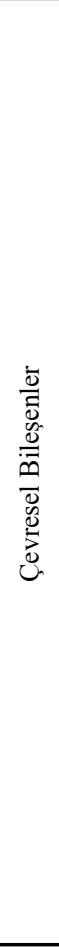 } & \multirow{11}{*}{$\begin{array}{c}\text { Fiziksel Çevresel } \\
\text { Bileșenler }\end{array}$} & \multirow[t]{4}{*}{ Coğrafi } & Sahil Şeridi & 9 & \multirow[t]{4}{*}{22.5} \\
\hline & & & Deniz & 5 & \\
\hline & & & Çarpık Yapılaşma & 4 & \\
\hline & & & Karşıyaka İskelesi & 2 & \\
\hline & & \multirow[t]{3}{*}{ Ticari } & Karşıyaka Çarşı & 5 & \multirow[t]{3}{*}{9} \\
\hline & & & İş & 2 & \\
\hline & & & Bankalar & 1 & \\
\hline & & \multirow[t]{3}{*}{ Ulaşım } & Fayton & 2 & \multirow[t]{3}{*}{5.6} \\
\hline & & & $\begin{array}{c}\text { Ulaşım Aktarma Merkezi } \\
\text { Olması }\end{array}$ & 2 & \\
\hline & & & Vapur & 1 & \\
\hline & & Ekolojik & Palmiye & 1 & 1.1 \\
\hline & \multirow{7}{*}{$\begin{array}{l}\text { Sosyal Çevresel } \\
\text { Bileșenler }\end{array}$} & \multirow[t]{2}{*}{ Sosyal Hayat } & Canlı Sosyal Hayat & 4 & \multirow[t]{2}{*}{5.6} \\
\hline & & & Tiyatro & 1 & \\
\hline & & \multirow[t]{2}{*}{ İnsanlar } & Seçkin İnsanlar & 3 & \multirow[t]{2}{*}{4.5} \\
\hline & & & Esnaflar & 1 & \\
\hline & & \multirow[t]{3}{*}{ Çeşitlilik } & Kalabalık & 2 & \multirow[t]{2}{*}{3.3} \\
\hline & & & Așırı Kozmopolitlik & 1 & \\
\hline & & & Toplam & 46 & 51.6 \\
\hline & \multirow{17}{*}{$\begin{array}{c}\text { Psiko-Sosyal } \\
\text { Bileșenler }\end{array}$} & \multirow[t]{6}{*}{ Aidiyet-Bellek } & Eski İzmir Nostaljisi & 5 & \multirow[t]{6}{*}{21.4} \\
\hline & & & KSK & 5 & \\
\hline & & & 35.5 & 5 & \\
\hline & & & Aidiyet & 2 & \\
\hline & & & Atatürk & 1 & \\
\hline & & & Demokrasi & 1 & \\
\hline & & \multirow{9}{*}{$\begin{array}{c}\text { Duygusal } \\
\text { (olumlu) }\end{array}$} & Rahatlık & 5 & \multirow[t]{9}{*}{24.8} \\
\hline & & & Güvenlik & 4 & \\
\hline & & & Huzur & 3 & \\
\hline & & & Dostluk & 3 & \\
\hline & & & Coşku & 2 & \\
\hline & & & Mutluluk & 2 & \\
\hline & & & Özgürlük & 1 & \\
\hline & & & Temizlik & 1 & \\
\hline & & & Sicakkanlılık & 1 & \\
\hline & & \multirow{2}{*}{$\begin{array}{l}\text { Duygusal } \\
\text { (olumsuz) }\end{array}$} & Düzensizlik & 1 & \multirow[t]{2}{*}{2.2} \\
\hline & & & Kasvet & 1 & \\
\hline & & & Toplam & 43 & 48.4 \\
\hline & & & Ana Toplam & 89 & 100 \\
\hline
\end{tabular}

bakıldığında, Șekil 4'te da görüldüğü üzere duygusal aktarımların çoğunlukta olduğu psiko-sosyal bileșenlerin \%41.3 oranıla öne çıktığı görülmektedir. Psiko-sosyal 


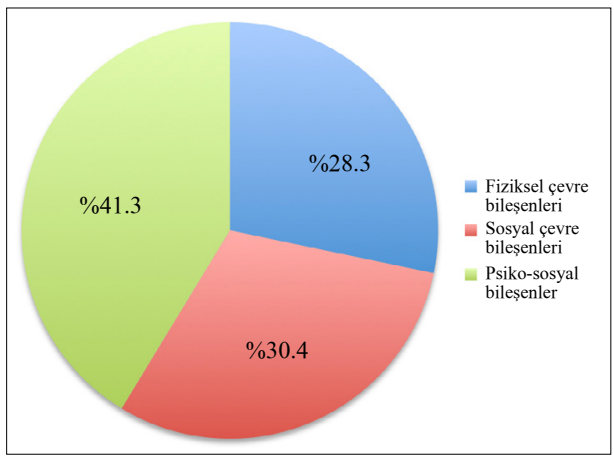

bileșenleri \%30.4 oranıla sosyal çevre bileșenleri ve $\% 28.3$ oranıyla fiziksel çevre bileşenleri takip etmektedir. Dağılım oranlarının birbirine oldukça yakın olması Karşıyaka'nın çok boyutlu bir algılama sürecine olanak veren yapıda bir kentsel mekân olduğu çıkarımına varılmasını sağlamaktadır. Aynı zamanda bu dağılım oranlarının çevresel algıda bilişsel (cognitive) ve duygusal (affective) süreçlerin önemini de ortaya koyduğu söylenebilir.

Karşıyaka'nın geçmişten bugüne en önemli imgelerinden biri olan deniz, sahil șeridi ve Karşıyaka Çarşı'nın fiziksel çevreye ait bir bileșen olarak hafizada en fazla yer alması ile günümüzde de çevresel algıdaki imgeselliğini ve anlamını koruduğu görülmüştür. Bunun yanı sıra canlı sosyal hayat ve seçkin insanlar sosyal çevre boyutunda, Karşıyaka Spor Klubü (KSK) - 35.5 gibi önemli kentsel bellek ögeleri ve rahatlık, güvenlik ve huzur gibi duygular ise psiko-sosyal boyutta Karşıyaka ile bağdaştırılan kimlik özellikleri olarak öne çıkmaktadır.

Katılımcılara Karşıyaka'da sevdikleri ve sevmedikleri özelliklerin neler olduğu sorulmuş ve Karşıyaka hakkında sahip olduğu duygular ortaya çıkarılmaya çalışılmıştır (Tablo 6). Bu sorularla mekâna karşı oluşan uzaklaşma- yaklaşma davranış biçimleri ortaya konmaya çalıșılmıştır. Çalışmada alınan cevapların \%65.3'ü olumlu ifadelerden oluşmaktadır. Olumlu ifadelerin çoğunluğunun güvenlik, sükunet, aidiyet, insan kalitesi gibi psiko-sosyal bileșenlerden oluştuğu görülmüş; özellikle aydın ve nezih insanlar gibi olumlayıcı sıfatlar öne çıkmış ve en yüksek frekansı oluşturmuştur. Bunların yanı sıra, deniz ve sahil șeridi olumlu olarak belirtilen en önemli çevresel faktör olarak öne çıkmıștır. Karșıyaka ile olumsuz ifadeler ise Karşıyaka'nın çok göç alması sonucunda aşırı kozmopolit bir hale gelmesi ve tanıdıklığın azalarak aidiyet duygusunun sekteye uğramasından oluşmaktadır. Sonuç olarak Karşıyaka hakkındaki olumlu ifadelerin baskınlığı daha önce Karşıyaka ziyaret sıklığı ile ilgili olan soruya \%59.1 oranında verilen "sıklıkla" yanıtıyla uyumlu biçimde katılımcıların ağırlıkla Karşıyaka'ya yaklaşma davranıșı geliștirdiğini ortaya koymaktadır.

\subsubsection{Bilişsel Haritalar Aracılığıyla Elde Edilen Sonuçlar}

Yapılan görüşmelerin ardından katılımcılardan zihinlerindeki Karșıyaka haritasını çizmeleri istenmiş, ve bu haritalarda duygu, düşünce ve yazılara yer verebilecekleri belirtilmiştir. Katılımcıların Karşıyaka'ya ilişkin zihinlerindeki çevresel imaj Lynch'in İmgelenebilirlik Teorisi'ndeki (Imageability Theory) beș strüktürel bileșene göre analiz edilmiștir (kenarlar, bölgeler, yollar, dïğüm noktaları ve işaret noktaları). 22 katılımcının 17'si harita çizmeyi kabul etmiștir, ancak 3 katılımcı çizim yapamadıklarında ısrarcı olup yalnızca yazı yazmışlardır. İki katılımcı ise kesin olarak çizim yapmayı reddetmiş ve yalnızca görüşme sorularını cevaplandırmışlardır.

Bilişsel haritalarda çiziler öge gruplarına bakıldığında kenarlar (\%28.3), düğüm noktaları (\%25) ve işaret ögelerinin (\%23.9) öne çıktığı görülmektedir (Tablo 7). Bu durum Lynch'in (2018) Jersey City'de yaptığ 1 alan araştırması sonuçları gibi yollara ve bölgelere kullanıcılar tarafindan çok önem verilmediğini göstermektedir. Lynch bunun sebebini çalışmanın yaya olarak yapılması ve bu sebeple kișilerin araç kullanımındaki yolları ihmal etmesi ve çalışmanın yapıldı$\breve{g} 1$ bölgedeki sosyal statünün katılımcıların bazı bölgeleri görmezden gelmesi olarak açıklamıştır. Bu açıklama bu çalışmadaki durum için de geçerli olarak görülebilir, zira çalışma yaya olarak ve Karşıyaka'nın belirlenen 3 bölgesinde yapılmıștır.

Haritada çizilen ögeler incelendiğinde ise görüşmelerde öne çıkan imgelerle örtüșen durumlar gözlenmektedir. Görüşmelerde Karşıyaka ile bağdaştırılıp imgeleştiği or-
Şekil: 4

Karşıyaka denince akla gelen bileşenlerin oranlarının grafik gösterimi. 
Tablo: 6

Karşıyaka hakkında kullanılan olumlu-olumsuz ifadeler ve oranları.

\begin{tabular}{|c|c|c|c|}
\hline & & Frekans (N) & Yüzde (\%) \\
\hline \multirow[t]{16}{*}{ Olumlu İfadeler } & İnsan Kalitesi & 12 & 65.3 \\
\hline & Sahil & 9 & \\
\hline & Sükunet & 9 & \\
\hline & Aidiyet Tanıdıklık & 5 & \\
\hline & Deniz & 4 & \\
\hline & Güvenlik & 3 & \\
\hline & Eşitlik & 3 & \\
\hline & Alışveriș İmkanları & 3 & \\
\hline & Canlı Şehir Hayatı & 3 & \\
\hline & Ulaşım İmkanları & 3 & \\
\hline & Düzen & 3 & \\
\hline & Parklar & 2 & \\
\hline & Özgürlük & 2 & \\
\hline & KSK & 1 & \\
\hline & Siyasi Görüşler & 1 & \\
\hline & Eski İzmir Hatıraları & 1 & \\
\hline \multirow[t]{16}{*}{ Olumsuz İfadeler } & Aşırı Kozmopolitlik & 7 & 34.7 \\
\hline & Kentsel Dönüşüm ve Betonlaşma & 5 & \\
\hline & Tanıdıklığın Azalması & 3 & \\
\hline & Trafiğin Artışı & 2 & \\
\hline & Kötü Koku & 2 & \\
\hline & AVM'lerin Çoğalması & 2 & \\
\hline & Tramvay & 2 & \\
\hline & Anadolu Cd. Üstündeki Yapılaşma Tanıdıklık & 2 & \\
\hline & Kötü Belediye Hizmetleri & 2 & \\
\hline & Monotonluk & 2 & \\
\hline & Sokak Hayvanlarının Çokluğu & 1 & \\
\hline & Dar Kaldırımlar ve Sokaklar & 1 & \\
\hline & Kapitalizm & 1 & \\
\hline & Sonradan Görmüşlük & 1 & \\
\hline & Bencillik & 1 & \\
\hline & Toplam & 98 & 100 \\
\hline
\end{tabular}

taya konulan deniz, sahil, Karşıyaka İskele, ve tanımlanabilir olması ve kişilerin o Karşıyaka Çarşı gibi ögeler haritalarda da çizilmiş ve katılımcıların Karşıyaka algısında önemli yer tuttukları bilgisi bilișsel haritalarla elde edilerek pekiștirilmiștir (Şekil 5).

\section{Tartışma ve Sonuç}

Bir kentin kullanıcılar tarafindan benimsenmesi ve kullanılması; kentin okunabilir mekânda aidiyet, güvenlik, sosyalleşme gibi temel ihtiyaçlarını giderebilmesini sağlayan nitelikli kentsel mekânlara sahip olmasıyla doğru orantılıdır (Lynch, 2018). Tüm bu parametreler Lynch'in İmgelenebilirlik Teorisi'nde (Imageability Theory) açıklandığı üzere kimlik, strüktür ve anlam ögelerine sahip bir kentsel imajla mümkün 


\begin{tabular}{|c|c|c|c|}
\hline & Ögeler & Frekans (N) & Yüzde (\%) \\
\hline \multirow[t]{2}{*}{ Kenar } & Deniz/Sahil & 18 & 28.3 \\
\hline & Ağaç dizisi & 8 & \\
\hline \multirow[t]{2}{*}{ Bölge } & Konutlar & 4 & 7.6 \\
\hline & Dükkanlar (Bostanlı) & 3 & \\
\hline \multirow[t]{5}{*}{ Yol } & Sahil YürüyüşYolu & 5 & 15.2 \\
\hline & Tramvay Yolu & 3 & \\
\hline & Girne Caddesi & 2 & \\
\hline & Yalı Caddesi & 2 & \\
\hline & Eshot Sokağ1 & 2 & \\
\hline \multirow[t]{5}{*}{ Düğüm Noktası } & Karşıyaka Çarşı & 12 & 25 \\
\hline & Mavibahçe & 5 & \\
\hline & KY İzban/Minibüs Durakları & 4 & \\
\hline & Atakent Kavşak & 1 & \\
\hline & Balıkçı Barınağ1 & 1 & \\
\hline \multirow[t]{9}{*}{ İșaret Ögesi } & Karşıyaka İskele & 9 & 23.9 \\
\hline & Karşıyaka İș Bankası & 5 & \\
\hline & Bostanlı İskele & 3 & \\
\hline & D\&R Karşıyaka & 1 & \\
\hline & Karşıyaka Çarşı Burger King & 1 & \\
\hline & Beşikçioğlu Camii & 1 & \\
\hline & Bostanlı Bravo Pastanesi & 1 & \\
\hline & Suat Taşer Açıkhava Tiyatrosu & 1 & \\
\hline & Toplam & 92 & 100 \\
\hline
\end{tabular}

olabilir (2018). Bunlara ek olarak, Mahrebian ve Russell'ın Uzaklaşma-Yakınlaşma Teorisi'nde (Avoidence-Approach Theory) ifade ettiği gibi bir mekâna dair olumlu duygular, o mekâna yaklaşma (approach), bir mekana dair olumsuz duygular ise o mekândan kaçınma (avoidence) biçiminde davranıșsal tepkilere neden olmaktadır (1974). Özetlemek gerekirse, kentin benimsenmesi ve kullanılması iyi bir kentsel imaj ve kente karşı oluşturulan olumlu duygusal bağlarla mümkün olabilmektedir.

Çalıșma kapsamında Karşıyaka'nın çevresel algısı bilişsel ve duygusal boyutlarıyla birlikte bütünsel olarak elde edilmiștir. $\mathrm{Bu}$ veriler katılımcıların Karşıyaka'yı ne sıklıkla kullandıklarını, hangi boyutlarıyla algıladıklarını, Karşıyaka'ya dair duygularının neler olduğunu ortaya koymaktadır. Katılımcı grubunun çoğunluğu Karşıyaka'da ikamet eden veya çalışan, dolayı- sıyla Karşıyaka’yı aktif olarak kullanan ve bölgeyi sıklıkla ziyaret eden kişilerden oluşmaktadır. İlçeye ulaşımın kolay olması da ayrıca kullanımı arttıran ve yoğun kentsel deneyimi sağlayan önemli bir parametre olarak görülebilir. Ziyaret sebeplerinde ve ziyaret edilen yerlerde alışveriș teması ve alıșveriș imkânı sunan Mavibahçe, Karşıyaka Çarşısı gibi mekânlar öne çıkmaktadır. Sosyalleşme ve yeme-içme mekanları, alışveriş aktivitesini izleyen ikinci önemli ziyaret yerleridir. Bu verilere bakıldığında Karşıyaka'nın gündelik hayatının oldukça hareketli olduğu, sıklıkla ziyaret edildiği, dolayısıyla Karşıyaka’ya ilişkin yakınlaşma (approach) davranışının (Mehrabian ve Russell, 1974) oluştuğu sonucuna varılabilir. Yakınlaşma davranışının oluştuğunu ortaya koyan bir diğer veri ise katılımciların Karşıyaka ile ilgili olumlu duygularının olumsuzlara göre daha baskın olmasıdır. 


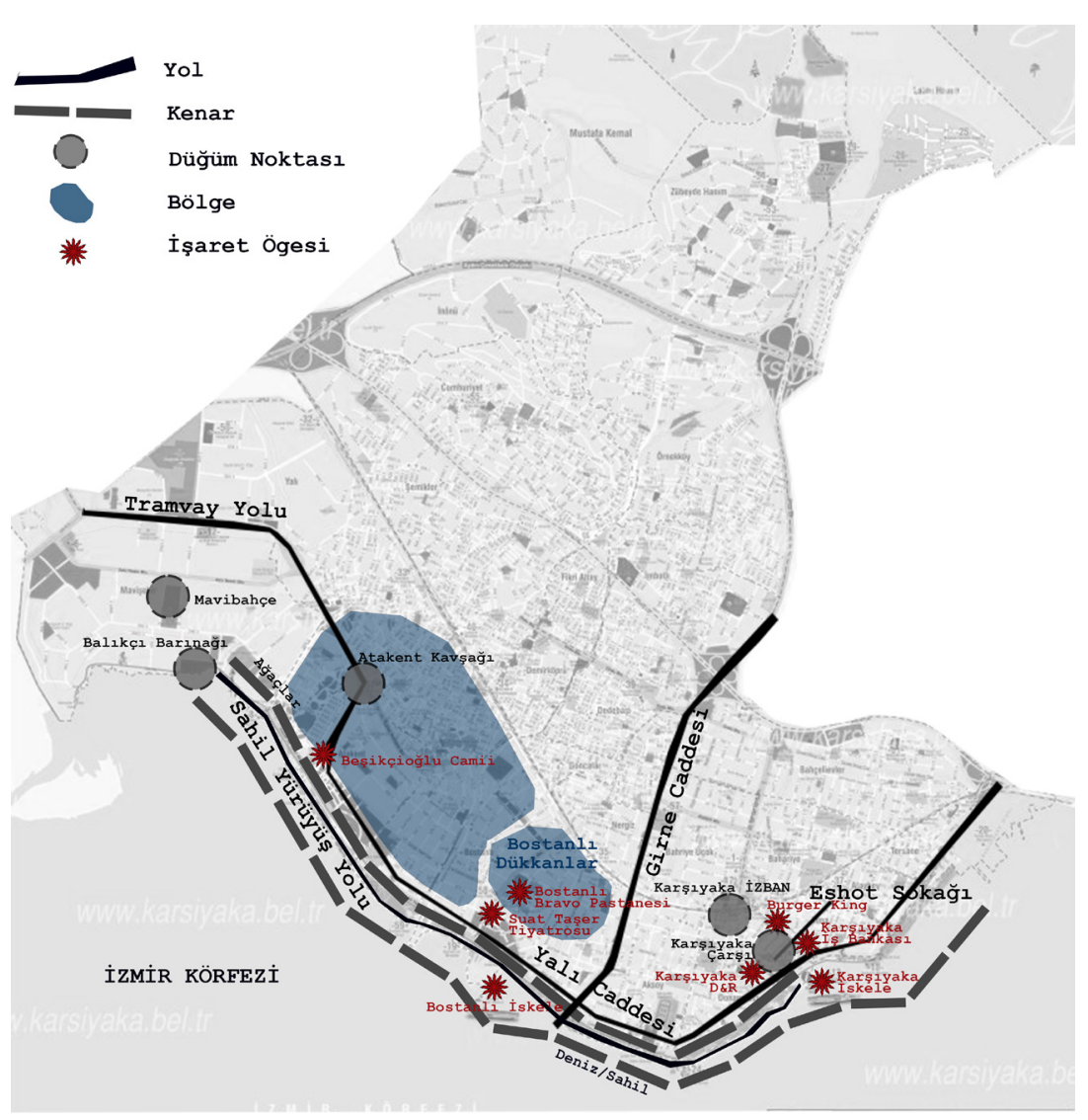

Şekil: 5

Bilişsel haritalardan elde edilen verilere göre Karşıyaka'nın imgesel ögeleri.
Karşıyaka algısının duygusal boyutunun yanı sıra bilişsel boyutu incelenirken katılımcılardan Karşıyaka denince akıllarına gelenleri sıralamaları istenmiștir. Böylece Karşıyaka'nın kullanıcıları tarafından hangi yönleriyle öznelleșerek kimlik kazand1$\breve{g} 1$, belleklerinde yer ettiği ve imgeleşerek anlamlandırıldığı Lynch'in İmgelenebilirlik Teorisi'nde bahsettiği kimlik ve anlam olguları bağlamında ortaya konmaya çalışılmıştır. Sahil șeridinin varlığı ve denize yakınlık Karşıyaka'nın tarihsel süreci boyunca hep önde olan faktörlerden olmuşlardır. Görüşmelerden elde edilen verilere bakıldığında günümüzde de sahil şeridi ve denizin kent belleğindeki yerini koruyarak duygusal ve bilişsel açıdan Karşıyaka kullanıcıları için önemli bir imge değerine sahip olduğu görülmektedir. Bunun yanı sıra kullanıcıların belirttiği Karşıyaka Çarşı, Karşıyaka Spor Klubü, seçkin insan profili, rahatlık, huzur ve güvenlik gibi bazı olgular da Karşıyaka'nın kimliğinin önemli parçaları olarak tanımlanmaktadır.
Katılımcıların bilișsel haritalarda çizdikleri öğelerle, görüşmelerden elde edilen veriler karşılaştırıldığında birbiriyle örtüșen Karşıyaka imgeleriyle karşılașılmıștır. Bu anlamda Karşıyaka'nın çevresel algısında sınır öğeleri olarak deniz, sahil ve sahildeki ağaçların, bölge olarak konut alanlarının, yol öğesi olarak Sahil yolunun, düğüm noktası olarak Karşıyaka Çarşı'nın, işaret noktası olarak ise Karşıyaka İskelesi'nin önemli yer tutuğu görülmüştür. Bölge ve yol bileșenlerinin algıda geri planda kalması, çalışmanın yaya olarak ve belli bölgelerde yapılması ve katılımcı sayısının az olması ile yorumlanabilir.

Özetlemek gerekirse, bu araştırmadan elde edilen sonuçlara göre Karşıyaka; ticari, sosyal, kültürel ve rekreatif açılardan olumlu kentsel deneyimler sunan, çok yönlü ve hareketli bir kamusal hayatın hüküm sürdüğü, yaklaşılan/ziyaret edilen bir yerleşim alanı olarak belirmektedir. Çeşitli ve kolay ulaşım olanakları, alıșverișe dair geniş yelpazede sunduğu imkânlar, zengin kültürel ajandası ve sosyalleșmeye olanak veren çok sayıdaki mekânı ile tarihsel süreçte olduğu gibi Karşıyaka bugün de kent belleğinde önemli yere sahiptir. Karşıaka bu araştırmada verimli olarak kullanılan, benimsenen, aidiyet kurulan, kullanıcıların kendilerine göre anlamlandırabildiği ve duygusal bağlar kurabildiği bir kentsel bölge olarak öne çıkmaktadır. Var olan olumsuzlukların çoğunluğunun trafik, ulaşım seçeneklerinin azaltılması, betonlaşma gibi fiziksel çevre bileşenleriyle alakalı olduğu düşünüldüğünde, belediye hizmetlerinin ve bu konudaki yasal düzenlemelerin daha kontrollü ve başarılı șekilde yürütülmesinin Karşıyaka kullanıcılarının memnuniyet düzeyini arttıracağı düşünülmektedir• 


\section{Kaynakça}

Appleyard, D. (1976). Planning a pluralistic city. Cambridge, MA: MIT Press.Arnheim, R. (2018). Görsel Düșünme. R. Oğdül (Çev.). İstanbul: Metis Yayınları.

Ayna A. ve Domaniçli F. S. (2011, Ekim). Duyusal Hacim. Mimari Tasarım Ĕ̆itimi: Bütünleşme içinde. İstanbul: Yıldız Teknik Üniversitesi.

Bahtiyar Karatosun, M. ve Olğun, T. N. (2017). İzmir Kıyı Kamusallığındaki Dönüșümün 19. Yüzyıldan 20. Yüzyıl Başlarına Uzanan Süreçte İrdelenmesi: Alsancak ve Karsıyaka Kıyıları Örneklemi. İzmir'de Kent, Mimarlık ve Kamusallık (s. 45-66) içinde. İstanbul: Yalın Yayıncılık.

Bakker I. \& Van der Voordt T. \& Vink P. \& De Boon J. (2014). Pleasure, Arousal, Dominance: Mehrabian and Russell Revisited. Current Psychology, 33(3), 405-421. doi: 10.1007/s12144-014-9219-4. Erișim adresi: https://www.levenswerken.eu/flash/ pleasure_arousal_dominance.pdf

Downs, R. M. ve Stea, D. (1973). Cognitive Maps and Spatial Behavior: Process and Products. R. M. Downs \& D. Stea (Ed.), Image and Environment (s. 8-26) içinde. Chicago: IL:Aldine

Eagleman, D. (2013). Incognito- Beynin Gizli Hayatı. Z. Arık Tozar (Çev.). İstanbul: Domingo Yayınları.

Erdoğmuș B. (2012). Bir Kıyı Yerleșmesinde Kimlik Dönüșümü: Tarihsel Süreç İçinde Karșıyaka'nın (İzmir) Kıyı Kullanımında Gözlenen Değișimler. Ege Cŏ̆rafya Dergisi, 21(2), 37-46. Erișim adresi: http://dergipark.gov.tr/download/ article-file $/ 56743$

Gärling T., Golledge R.G. (1989). Environmental Perception and Cognition. E.H. Zube ve G.T. Moore (Ed.). Advance in Environment, Behavior, and Design Vol. 2 içinde. Springer, Boston, MA. doi: 10.1007/978-1-4613-07174 7. Erișim adresi: https://link.springer.com/ chapter/10.1007/978-1-4613-0717-4_7\#citeas

Gibson, J. J. (1966). The senses considered as perceptual systems. Boston: Houghton \& Mifflin.

Golledge, R. G. (1999). Human wayfinding and cognitive maps. R. G. Golledge (Ed.), Wayfinding Behavior: Cognitive Mapping and Other Spatial Processes (pp. 5-45) içinde. Baltimore, MD: The Johns Hopkins University Press. Erisim adresi: https://books.google.com.tr/books?id=TjzxpAWi amUC\&printsec $=$ frontcover $\# \mathrm{v}=$ onepage $\& \mathrm{q} \& \mathrm{f}=$. false

Ittelson, W. H. (1973). Environment perception and contemporary perceptual theory. W. H. Ittelson (Ed.), Environment and cognition içinde. New York: Seminar.

Ittelson, W. H. (1978). Environmental Perception and Urban Experience. Environment and Behavior, 10(2), 193-213. doi: 10.1177/0013916578102004 Erisim adresi: https://journals.sagepub.com/doi/ abs $/ 10.1177 / 0013916578102004$

İnceoğlu M. (2010). Tutum Algl İletişim. İstanbul: Beykent Üniversitesi Yayınları.

Karadağ A. ve Turut H. (2013). Üniversite Öğrencilerinin Kentsel Çevre Algısı Üzerine Bir Araștırma: İzmir Örneği. Coğrafi Bilimler Dergisi, 11(1), 31-51. Erișim adresi: http://dergiler.ankara.edu.tr/ dergiler/33/1910/20050.pdf

Karakuş P. (2007). İzmir Kültürparkı'nın, İzmirliler Açısından Anlamı ve Kültürpark Hakkındaki Temsilleri (Yüksek lisans tezi). Ege Üniversitesi Sosyal Bilimler Enstitüsü. YÖK veritabanından erisildi. (Tez No: 221630)
Lang, J. (1994). Urban design: the American experience. John Wiley \& Sons.

Lange, E. (2005, May1s). Issues and Questions for Research in Communicating with the Public through Visualizations. Trends in Real-Time Landscape Visualization and Participation: Proceedings at Anhalt University of Applied Sciences konferansında sunulan bildiri, Dessau, Almanya. Erişim adresi: http://193.25.34.143/studiengaenge/mla/ $\mathrm{mla}$ _fl/conf/pdf/conf2005/11lange_c.pdf

Lefebvre, H. (2002). Critique of Everyday Life, Volume II. J. Moore (Çev.). London and New York: Verso.

Lewin, K. (1951). Field theory in the social sciences. New York: Harper.

Lynch K. (2018). Kent İmgesi. İ. Başaran (Çev.). İstanbul: Türkiye İs Bankası Kültür Yayınları. (Orj. Basım Tarihi: 1960).

Maslow, A. H. (1954). Motivation and Personality. New York, NY: Harper \& Row Publishers.

Mehrabian, A., \& Russell, J. A. (1974). An approach to environmental psychology. USA: The Massachusetts Institute of Technology.

Milgram, S. (1970). The experience of living in cities Science, 167(3924), 1461-1468. doi: 10.1126/ science.167.3924.1461. Erișim adresi: https:// www.jstor.org/stable/1728966?seq=1\#metadata_info_tab_contents

Norberg - Schulz, C. (1980). Genius Loci: Towards a Phenomenology of Architecture. New York: Rizolli.

Nasar, J. L. (1998). The evaluative image of the city. ABD: Sage Publications

Pallasmaa J. (2018). Tenin Gözleri. İstanbul: YEM Yayınc1lik.

Rapoport A. (1977). Human Aspects of Urban Form. New York: Pergamon Press

Sağsöz A.ve Al S. (2013). Kent İçinde Bir Yapı, Yapı İçinde Bir Kent. Sanat Tarihi Dergisi, 22(2), 91-109. Erișim adresi: http://dergipark.gov.tr/download/ article-file/152516

Selçuk F. \& Türkseven Doğrusoy İ. (2016). Can Cognitive Mapping Be An Alternative Tool For The Participatory Rehabilitation Of Historical Urban Spaces? The Case Of Kemeraltı Bazaar In Izmir Turkey. Archdesign '16 Proceedings Book (s.325334) içinde. İstanbul: Dakam Yayınları.

Sormaykan, T. (2008). 1950'den Günümüze Karşıaka'da Apartman Tipi Konut Yapılarındaki Mekânsal Değişim ve Dönüşümler. Yüksek lisans tezi, Dokuz Eylül Üniversitesi Fen Bilimleri Enstitüsü. YÖK veritabanından erișildi. (Tez No: 244605)

Steiner, R. (1981). Man's twelve senses in their relation to imagination, inspiration, intuition. Anthroposophical Review, 3(2), 12-19. Erisim adresi: https://www.waldorflibrary.org/images/ stories/articles/twelvesenses.pdf

Tanaç Kiray, M. (2006). Karşıyaka Çamlık Sokak'ta 1950'l Y1lların Tekil Konut Mimari Karakterini Tasıyan Üç Ev. Ege Mimarlık, 3(58), 40-43. Erișim adresi: http://www.izmimod.org.tr/egemim/58/40-43.pdf

Türkseven Doğrusoy İ. (2017). Kentsel Kamusal Mekânda Duyusal Analiz ve Tasarım: Tarihi Kemeraltı Çarşısında Bir Eğitim Deneyi. İzmir'de Kent, Mimarlık ve Kamusallık (s. 133-164) içinde. İstanbul: Yalın Yayıncılık.

Uz A. ve Uz N. (2017). Sehir ve Heykel, Sehirde Heykel, Şehirlerin Sembolleri Heykeller. ASEAD, 4(12), 721-730. Erișim adresi: http://www.asead.com/ FileUpload/bs683328/File/721-730 uz-uz.pdf 
Yazıcıoğlu Halu Z. (2010). Kentsel Mekân Olarak

Caddelerin Mekânsal Karakterinin Yürünebilirlik

Bağlamında İrdelenmesi Bağdat Caddesi Örneğ

(Doktora tezi). İstanbul Teknik Üniversitesi Fen

Bilimleri Enstitüsü. YÖK veritabanından erișildi.

(Tez No: 293851)

Yıldırım A. ve Șimșek H. (2013). Sosyal Bilimlerde

Nitel Araştırma Yöntemleri. Ankara: Seçkin

Yayıncılık. (Orj Basım Tarihi: 1999). 